\title{
Virumaa hiied
}

\author{
Ahto Kaasik
}

Teesid: Hiis on ajalooline looduslik pühapaik, millega seostub ohverdamisele, pühakspidamisele, ravimisele, palvetamisele või muule usulisele või taialisele tegevusele viitavaid pärimuslikke andmeid. Üldjuhul on hiis küla pühapaik, rahvapärimuse järgi olevat varem olnud igal külal oma hiis. Samas on mõnda hiiepaika kasutanud terve kihelkond.

Artiklis on vaatluse all Virumaa pühapaigad ning ära on toodud Virumaal praeguseks teada olevate hiite nimekiri.

Märksõnad: hiis, looduslik pühapaik, Virumaa

Eestis on ajalooliste andmete põhjal teada ligikaudu 800 hiit, neist ligi kuuendik Virumaal. Arvestades, et andmed hiitest on jõudnud meieni läbi aastasadade täis sõdu, taude, otsest hävitamist ja ärakeelamist ning usundilise maailmapildi muutumist, on see aukartustäratav hulk.

Hiis ühendab kogukonda ja laiemalt rahvast. Hiis täidab õige erinevaid ülesandeid ning on midagi enamat kui looduskaitseala, kooskäimis- või tantsukoht, vallamaja, haigla, kalmistu, kirik, kohtumaja, kindlus või ohvrikoht. Hiie suhtes puudub tänapäeval kohane võrdlus. Hiis on hiis. Ajalooliste looduslike pühapaikade hulgas moodustavad hiied eraldi rühma. Samma küla Tammealuse hiide on rahvast mäletamistmööda kogunenud kogu Mahu (Viru-Nigula) kihelkonnast (Kaasik 2001; Maran 2013).

Hiienimelised paigad on ajalooliselt levinud peamiselt põhja pool Tartu Viljandi - Pärnu joont (Valk 2009: 50). Lõuna pool võidakse sarnaseid pühapaikasid nimetada kergo-, kumarus-, pühä-, ahi- vm paigaks. Kuid ka Virumaal ei nimetata hiiesarnaseid paiku alati hiieks. Selline on näiteks Lavi pühapaik.

Hiietaolisi pühapaikasid leidub meie lähematel ja kaugematel hõimurahvastel. Sarnased on ka pühapaikadega seotud tõekspidamised ja tavad. Nõnda annavad hiied olulise tähendusliku lisamõõtme meie kuulumisele soome-ugri 
rahvaste perre. Ja see pole veel kõik. Hiiesarnaseid pühapaikasid leidub samuti paljudel teistel maailma põlisrahvastel. Hiied on inimkonna iidne ühine loodus- ja vaimupärand (IUCN 2011: 5).

\section{Kus on hiie ase?}

Esmapilgul näib, et hiite paiknemisel maastikus pole selget seaduspära. Neid asub kõrgendikel (Kuremäe, Kunda, Ebavere), tasandikel (Kestla, Vasta, Pauliku), soosaartel (Varudi, Roostoja, Aidu), jõekaldal (Samma, Pühajõe, Loobu) või mererannal (Männiku, Vihasoo, Purtse). Kõikvõimalike maastikuvormide hulgas võib hiites leida isegi karstilohkusid (Kalina, Ratva).

Võrreldes hiite asukohti ajaloolise asustusega, leiame aga silmatorkava korrapära. Olgugi, et üksikud hiiepaigad asuvad kaugetes laantes või soosaartel, asub enamus neist siiski vanade külasüdamete lähedal (Kaasik 2011: xiii). Eemal igapäevastest askeldustest, kuid silmsideme kaugusel. Rahvapärimuse põhjal võib oletada, et mõnestki pelgupaigast on saanud olude sunnil hiiepaik.

Iisaku kihelkonnast on kirjapanek:

Roogendiku talust Roostoja külas 2 kilumeetrit raba sees on Iissaar. Ennemalle, kui ristiusk meie maale toodi, läksivad eestlased salaja vanu jumalaid kummardama. Nad tulivad mailma kaugelt läbi rabade ja soode soosaartele, seal olivad nende pühad hiied. Seal nemad ohverdasid siis oma andisid, mis neil oli, ja palusivad oma jumalaid. Iissaar oli ilus kõrge saar kesk lagedat raba, seal kasvasivad suured puud: kased, kuused, männid, haavad. (RKM II 61, 27/8 (12) < Iisaku khk, Lõpe k-M. Proodel < Kristof Roostari (1881-1944) käsikirjadest (1956)).

\section{Hiies on erinevaid paiku}

Hiie pindala võib ulatuda vähem kui hektarist saja hektarini ning selle alal võib sageli kohata erinevaid vaimseid keskusi: üksikuid pühi kive, puid, allikaid, kalmeid, tantsukohti jm (Kaasik 2007: 34). Kunda Hiiemäel näiteks on asunud püha allikas, kivi ning kalmed.

Puud. Tavaliselt on hiis tuntud puudesaluna - nt tammikuna. Ometi võivad hiiepuuks olla kõik kodumaa puuliigid. Tingimuseks on vaid, et maa, millel nad kasvavad, on tuntud kui hiiepaik. Erinevatel maastikel ja kasvukohatüüpidel kasvavad erinevad hiiemetsad: männikud, pärnikud, kaasikud, tammikud, kuu- 


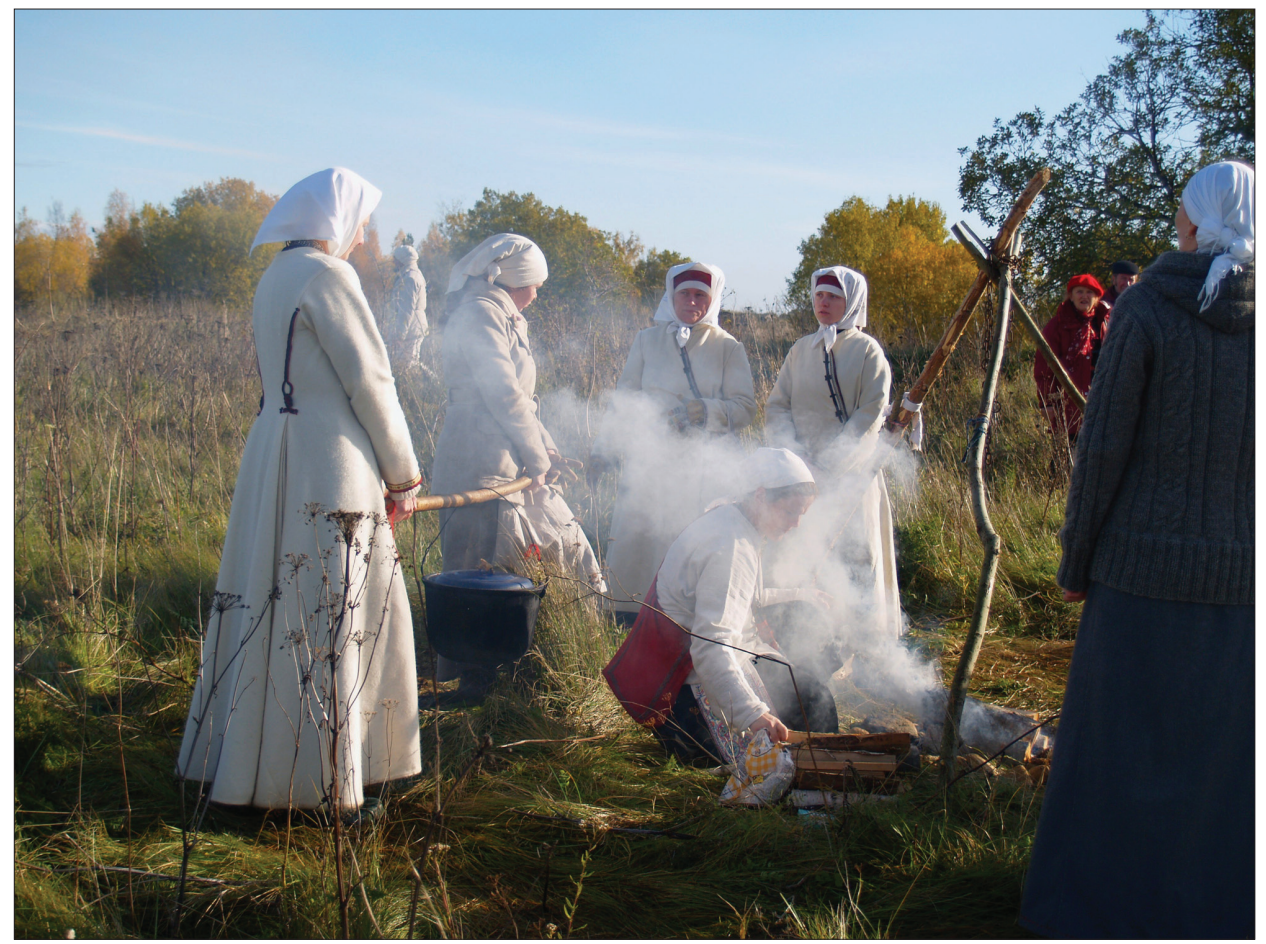

Foto 1. Hingedeaja palvuse pudru keetmine Kunda Hiiemäel. Heiki Maibergi foto 2009.

sikud, lepikud, saarikud, haavikud, kuid kõige sagedamini siiski segametsad. Tänapäeval leiame Virumaal vaid mõne hiiesalu. Peamiselt kohtame üksikuid hiiepuid ja veel enam mälestusi nendest, nt Ilumäel, Amas, Neerutis jm.

Kivid. Virumaal on arvatud, et igas hiies peab olema hiie- või ohvrikivi. Tegelikult polnud lugu nii enam möödunud sajandeilgi. Paljud kivid leidsid oma lõpu mõisate jt hoonete seintes. Seepärast on kive ka peidetud. Näiteks Kalina hiies olevat kolm meest kaevanud Uku kivi maasse, kuna vennastekogudus tahtis seda teotada või hävitada. Ühes Simuna khk üleskirjutuses on juttu koguni kahest kivist, kuhu ande viidud.

Tammiku maa pial Salla vallas oli old üks iietammik, kus käidi ütleme pühasid pidamas ja Taarad kummardamas. Taara oli vana jumal. Oli iietammik ja taaratammik. Sial oli siis iiekivi ja ohvrikivi, mõlemad sial tammikus. Ohvrikivile viidi mitmesuguseid ohvreid, kui taheti, et luomad ästi korda lähevad. Mitmesuguseid toiduaineid viidi sinna. Ja kõik inimesed viisid, kel oli midagi palumist. Kes selle ohvri ära viis 


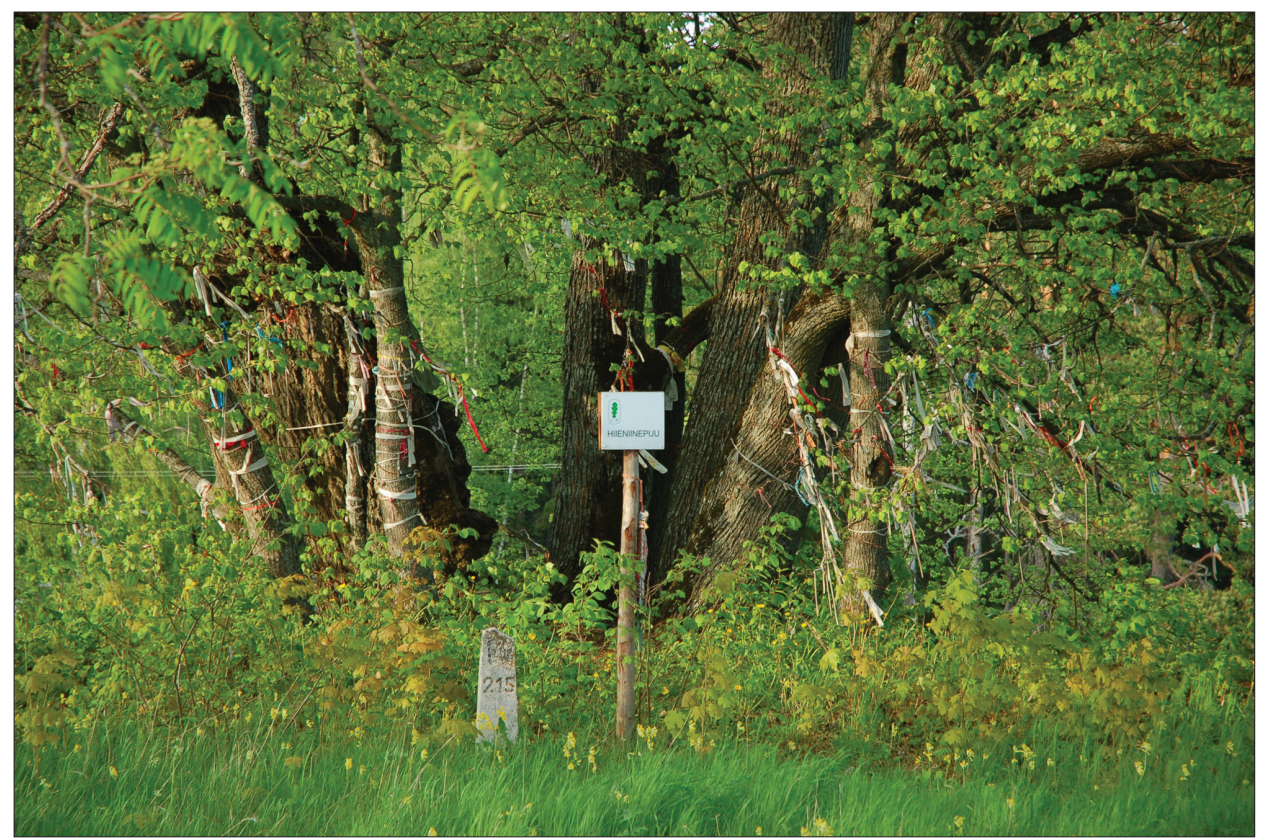

Foto 2. Ilumäe Hiieniinepuu andidega. Kadrina kihelkond. Ahto Kaasiku foto 2008.

või pruukis, seda ma ei tia. Aga iiekivile viidi ütleme ka andisi sinna: pärgasi, paelu ja ka piarätikuid. Ohvrikivile viidi seda, mis süia kõlbas, iiekivile rohkem ehteassu. Sie oli iiekivi ja ohvrikivi vahe. Sest iiekivisi oli iga küla läheduses arva, neid põld mujal kui iies. Aga ohvrikivisi oli iga küla juures kas kaasikus ehk koplis. (RKM II 349, 289/90 < Simuna khk, Avanduse vanadekodu - H. Joonuks < Juhan Rääk (1947))

Veekogud. Tihti asub hïies või selle läheduses allikas või mõni muu veekogu. Pühi allikaid leidub Uku, Vatku, Ilumäe hiies jm. Ilmselt pole juhus, et ka suuremate veekogude kallastel leidub hiiepaiku. Jõgede kallastel asuvad näiteks Kunda hiiemägi, Samma Tammealuse hiis ja Pühajõe hiis, mererannal Purtse hiiemägi, Vihasoo Kõrgemäe hiis ja Martsa hiis. Kuivanud on Tudu hiiejärv ja Rutja Iidjärv, samuti Tõrma hiiemäe kõrval voolanud püha jõgi.

Kujud. Henriku Liivimaa kroonikas kõneldakse, kuidas katoliku preester raiunud arvatavalt Ebavere mäel maha meie jumalate kujud ja näod (Henrik 1993: 155). Nii on olnud põhjust arvata, et maarahvalgi on pühapaikades seisnud jumalate kujud. Rahvapärimuse järgi asunud Viru-Nigula (Mahu) kihelkonna Männiku küla hiielepikus jumalate kujud, mida käidi kummardamas. 


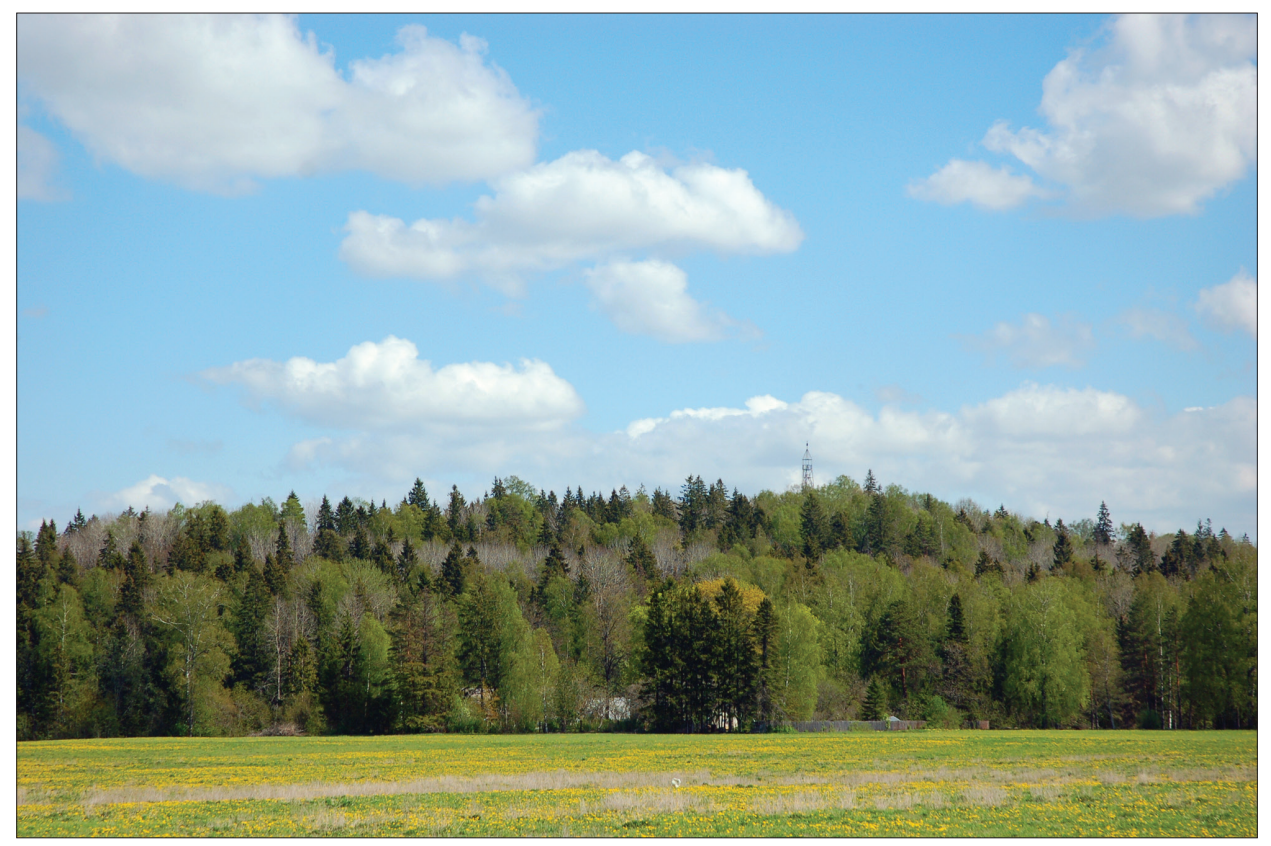

Foto 3. Hiiemets Ebavere mäel. Väike-Maarja kihelkond. Ahto Kaasiku foto 2007.

Tantsu- ja mängukohti on teada mitmetest hiitest. Tantsud ja ringmängud on tihedalt seotud kevadsuviste pühade kombestikuga. Tundub, et selliseid paiku on rahvas väga armastanud ja käinud mõneski hiies pidutsemas kaasajani välja, nt Sammas, Tõrmas, Aburis jm.

Nõupidamiskoht. Rahvapärimus vahendab ettekujutust hiiest salajaste nõupidamiste kohana. Nt Purtse Hiiemäel teinud rahvavanemad tule üles, kui tahtsid rahvast nõupidamisele kutsuda.

Matmiskoht. Hiie ja kalme vahele ei saa panna võrdusmärki, kuid paljudest hiitest on leitud matusekohti. Kalmed asuvad tavaliselt hiie äärealadel (Purtse, Ebavere, Iila). Kunda Hiiemäe kivikalme muinasteaduslikul uuringul määrati selle vanuseks vähemalt 2500 aastat (Mazur 2005). Kuid hiitesse on maetud hiljemgi. Mõdriku Tammaru Hiiemäel on kohaliku talupere kalmud.

Ehitised. Hiite ümber on ehitatud tarasid ning küllap oli(d) siis ka värav(ad). Rahvapärimus kõneleb hiiesaunadest ning mainitud on hiieaita. Leidub veel hiieküüne, -keldreid, -sildu, -kaeve, -külasid, -talusid ja -tänavaid. Kõik need 
on nime saanud mõnelt lähedal asuvalt hiielt, välja arvatud mõned uuemad talud ja tänavad.

\section{Hiierahvas}

Virulasi võib pidada hiierahvaks. Hiite rohkus ja nendega seotud rikkalik pärimus annab selleks alust. Hiie asukaist on 19. ja 20. sajandil talletatud rahvapärimuses kõige sagedamini mainitud jumalaid, hiie jumalaid, vanade eestlaste jumalaid või vanu jumalaid. Veel on nimetatud vaime, hiievaime, hiielasi, hiiehaldjaid jm olendeid. Usuti, et Samma Tammealuse hiietammes elas vanade eestlaste jumal, Tudu hiies haldjas või vaim jne. Jumalatest mainitakse kõige sagedamini Ukut, Äi(u)kest, Pikset, Vanajumalat ehk Taevaisa (Äntu, Repniku, Jäola). Mitmel pool on kõneldud hiitega seoses erilistest inimestest, keda võiks üldistavalt nimetada hiietarkadeks. Soonurmes elas Uku-nimeline perekond, kelle esiisa olnud küla hiies asjameheks. Repniku Hiiemäel aga ennustanud külatark tulevikku ja andnud rahvale head nõu.

\section{Lähme, hellad, hiisi mööda}

Niimoodi kutsuvad regilaulu sõnad. Rahvapärimuse järgi käidud hiies palvetamas, tänamas, andi viimas, nõu pidamas, ravimas, tuld tegemas, tantsimas, laulmas, pilli mängimas, kadunuid matmas ja austamas ning sõjapaos. Hiies on käidud pühade ajal ning enne tähtsamaid ettevõtmisi. Sinna on viidud oma mured, rõõmud ja lootused. Hiiepuudele, -kividele ja -allikatele on austuse märgiks kummardatud. Paljude teistegi põlisrahvaste tavandis on kummardamisel kui austuseavaldusel oluline koht.

Üks tähtsamaid hiitega seotud tavasid näikse olevat hiies käimine. Eks ole ju ka pühapaika minek tegevus. Aga alati ei ole võimalik hiide minna. Sagedamini kui jalad, viivad igapäevaste toimetuste keerises sinna mõtted. Pühapaigaga vaimses sidemes olemine, sealt mõttes toetuse ja jõu ammutamine on kõige olulisem hiietava.

\section{Hiiepühad}

Rahvapärimuses rõhutatakse sageli, et hiiepühad on olnud rahvarohked ja rõõmsad. Lisaks palvetamisele on seal lauldud, tantsitud ja pilli mängitud. 
Võime olla üsna kindlad, et paljude põlvkondade jooksul on hiites kõlanud regilaul, kannel ja torupill.

Mõned pärimusteated mainivad pühapaigas käimise ajana jõululaupäeva, uusaastapäeva, taliharjapäeva, liugupäeva, karjalaskepäeva, suvisteid, jaanilaupäeva, karusepäeva, rukkiemapäeva, hingedeaega ja teisi pühi. Nädalapäevadest on sageli mainitud neljapäeva.

\section{Tähendus ja tavad}

Hiis ja püha on rahvasuus sageli ühetähenduslikud. Hiietavadega sarnased ajaloolised käitumispõhimõtted seostuvad eesti rahvakultuuris teiste pühade paikadega - kalmistu ja saunaga, samuti tähenduslike päevadega. Ka on usutud, et kui läheduses on hiis, kaitseb see pikseõnnetuste, sõjakahjude, varguste ja tõbede eest. Hiies ei niideta rohtu ega korjata marju ja seeni, ei peeta jahti ega püüta kala. Püha ja puutumatu on kõik, mis hiies võrsub. Puutumatu on ka hiie maapind. Esivanemad on rõhutanud, et hiiest ei või oksagi murda. Olgu see vana hiiepuu, nooruke väät või põõsas - kuni see seisab püsti, ei või seda raiuda ega murda. Maha langenud vanad hiiepuud jäetakse oma kohale ja lastakse rahus mullaks ja uueks eluks muutuda. Eeldades, et puhtus, rahu ja vägivallatus iseloomustavad üldiselt hiietavasid, võiks seda loendit jätkata. Pühapaika minnakse puhtana ja puhtas rõivas. Seal hoidutakse riiust, vandumisest ja kurjadest mõtetest. Hiies ei tehta mõtte, sõna ega teoga liiga ühelegi olendile. Loomulikud vajadused tuleb rahuldada mujal. Puhtuse hoidmise pärast ei lasta hiide kodu- ja lemmikloomi. (Kütt 2007)

Rahvas teab palju hoiatavaid lugusid, kus hiietavade rikkujat on tabanud õnnetused, haigused või isegi surm. Kui vanemad pärimusteated on umbmäärased, siis uuemate juhtumite puhul kõneldakse nimeliselt kindlatest isikutest ja peredest. Inimeste teadlikkus pühapaikadest on vähenenud, kuid hiite vägi on loodusjõuna tajutavaks jäänud.

\section{Hiied kirve all}

Hästi hoitud hiis on põlismets, mis rikastab maastikku ning pakub varju paljudele eluslooduse liikidele. Hiied on meie rahva muistsed looduskaitsealad, mida tuleks kasutada üksnes ajalooliste tavade järgimiseks. Kahjuks on sellised hiied muutunud haruldaseks. Eelmiste sajandite ja aastakümnete jooksul on enamus hiiepaikasid rikutud või isegi hävitatud. Hiiepaikades palvetajaidki 


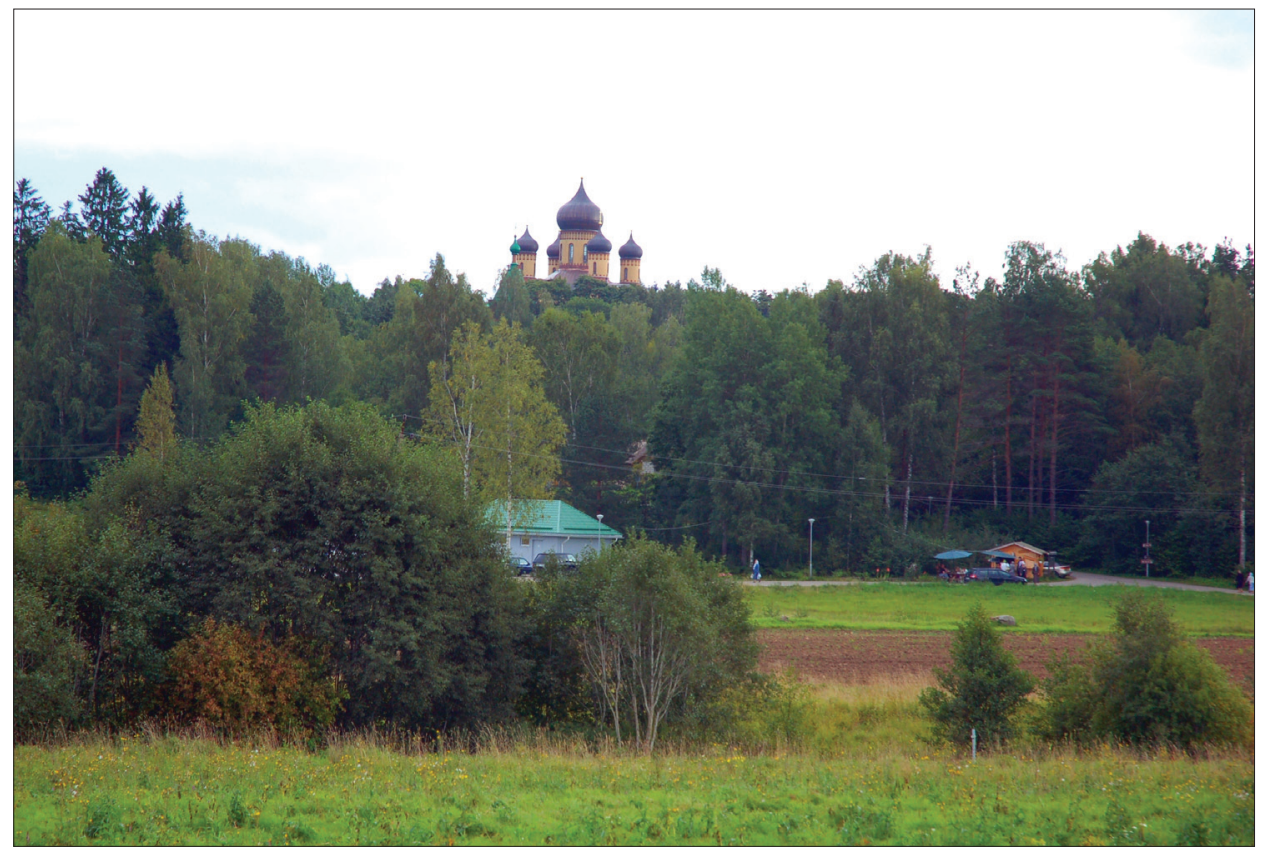

Foto 4. Õigeusu nunnaklooster on ehitatud Kuremäe Hiiemäele. Ahto Kaasiku foto 2009.

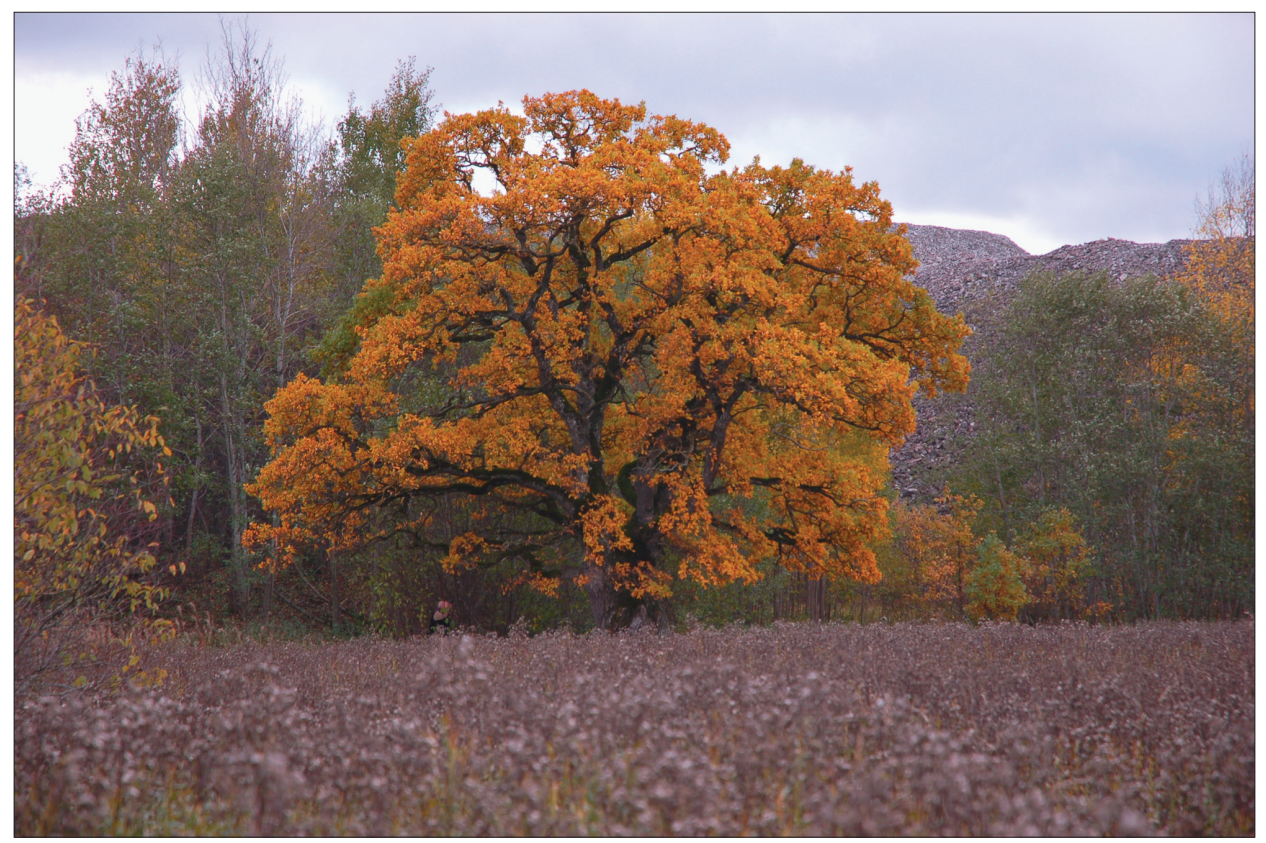

Foto 5. Tammiku-Pauliku hiis. Jõhvi kihelkond. Ahto Kaasiku foto 2006. 
on karistatud ja taga kiusatud. Jõhvi hiide on ehitatud kindluskirik, Kuremäe Hiiemäele õigeusu klooster, Kalina hiide mõis, Tammiku-Pauliku hiie kohal lasub nõukogudeaegse põlevkivikaevanduse aherainemägi, Kunda Hiiemäest kaevandati osa maanteede täiteks, Repniku Hiiemäest veeti suur osa Narva soojuselektrijaama ehituseks, Tõrma Hiiemäele ehitati silohoidla, Võrkla Salumäele mobiilimast, Ebavere hiiemäele spordirajad. Majandustegevus kahjustab praegugi suuremat osa hiitest. Põllumajanduslike eurotoetuste lootuses on haritud üles isegi söötis pühapaiku.

Enamik inimesi peab aga hiite kaitsmist oluliseks. 2014. aastal korraldatud avaliku arvamuse uuringu kohaselt peab hiite ja teiste looduslike pühapaikade kaitsmist tähtsaks või väga tähtsaks $84 \%$ eestimaalastest (Hiite Maja, Faktum Ariko 2014). Sellisel hoiakul on sügavad vaimsed juured. Erinevate uuringute põhjal usub 65\% eestlastest, et taimedel või puudel on hing (Moor 1998: 104; Altnurme 2011). Kirjanik Berk Vaheri sõnul on hiied eestlaseks jäämise kaitsealad (Vaher 2003). Hiied hoiavad põlisrahva vaimset järjepidevust ning toetavad looduslähedast eneseteadvust. Hiiepaikades võime tajuda esivanemate lähedust ja looduse pühadust. Hiiekohad ning neid puudutavad mälestused ja muistendid elavad edasi koos meiega. Nad on osa meie rahvast. Tänapäevalgi pole taandunud usk hiiepuudesse kui heatahtlikesse, kaitsvatesse olevustesse.

\section{Virumaa hiite nimekiri}

Valdav osa hiisi puudutavast seni kogutud teabest asub muuseumides ja arhiivides. Peamiselt selle põhjal on koostatud ja avaldatud käsitlusi hiite tähendusest. Põhjalikumad teistest on Mauno Koski (1967, 1970) ja Mari-Ann Remmeli (1998) uurimused. 2014. a seisuga on Hiite Maja ning Tartu Ülikooli looduslike pühapaikade keskuse juhtimisel looduslikud pühapaigad täies mahus kaardistatud üksnes Muhu, Juuru, Põlva ja Võnnu kihelkonnas. Arhiiviteadetele keskenduv osaline eeluuring on tehtud Kuusalu khk põhjaosas Hargla, Räpina, Kanepi, Kambja, Tartu-Maarja ja Nõo kihelkonnas (Kaasik 2016: 285). Ammendavam ja täielikum hiite ülevaade aga veel puudub, samuti ka terviklik teabekogu. Pühapaikade ulatuslikumad uuringud on Virumaal seni toimunud üksnes muistses Mahu kihelkonnas. 2003. aastal korraldas Maavalla koda seal hiite ülevaatuse prooviaasta raames eeluuringud.

Paiguti on hiiepaikasid puudutav pärimuslik ja muu teave väga napp ning piirdub üksnes kohanimega. Seepärast keskendub siintoodud Virumaa hiite nimekiri hiie nimetusele. Esitatud on kõik sellised teadaolevad kohanimed ning eelistatud on häälduspärast nimekuju. Näiteks kui kirjalikes allikates on mainitud Hiiemäge ja Iiemäge, on siinsesse loetellu võetud üksnes Iiemägi. 
Valikusse on võetud vaid ajaloolised nimed. 20. sajandil pandud hiie-talunimed, kus ajaloolist pühapaika pole teada, on jäetud kõrvale. Virumaa hiite nimekirjas pole ka muid looduslikke pühapaiku (ligikaudu 200), nagu üksikuid pühi puid, allikaid, kive jms, mida pole hiiega seostatud. Ühtlasi on välja jäetud hiietaolised paigad, mida teadaolevalt pole hiieks nimetatud. Kihelkonnad ja asukohti määratlevad külad on esitatud tähestikulises järjekorras ning ViruNigula khk asemel on Taani Hindamisraamatu 13. sajandi alguse asustuspildi alusel kasutatud Mahu kihelkonna ajaloolist maakeelset nimetust. Külanimede puhul on jäädud pärimustekstides kasutatud ajalooliste nimede juurde. Näiteks praeguse ametliku Vaivara kihelkonna Hiiemetsa asemel on varasem Repniku.

Esitatud hiite nimekiri pole lõplik. Täiendavad arhiivi- ja välitööd toovad siia edaspidi kindlasti täpsustusi ja täiendusi.

\section{Haljala kihelkond}

Iiemägi, Hiieväli, Hiie ja Hiiemäe talu Aasperes.

Hiis, Hiie koht, Iie Tooma talu Ama külas.

Hiiemets Altja külas.

Iidumäe rüngas Aukülas.

Iiesuane heinamaa Eisma ja Kandle vahel.

Ijeallik Kalikülas.

Hiienurga talu Kandle külas.

Iiesilla küün Karulas.

Iiemägi, Hiiekivi, Hiiepealne Katela külas.

Iije heinamaa, Hiiemets Kiva külas.

Iijekivi Kärmu külas.

Iisimäe talu, Ijemäe maja, Iiemäe kivi Käsmu külas.

Laagrimäe hiis Liiguste külas.

Ijemets, Hiiemägi Loobu külas.

Hiiekoht Läsna külas.

Hiiemets Metsameeste külas.

Hiiealune heinamaa Metsanurga külas.

Iijekivi Pehka külas.

Iidjärv, Hiidjärve nõmm Rutja külas.

Iiekännu heinamaa Sagadis.

Iie koht, Iie niit Vihulas.

Lisaks on mainitud, et Sagadi, Metsiku ja Annikvere külas täitsid hiite aset niinekingud. 


\section{Iisaku kihelkond}

Tubniku hiis Imatu külas.

Hiiemägi, Hiietamm ja Hiieallikas Kuremäel.

Hiieküngas ja hiieväli Oonurme külas.

Iissaar Roostoja külas.

\section{Jõhvi kihelkond}

Hiis Jõhvi Mihkli kiriku kohal.

Iis, Iiekaev, Iielepp, Iiepõllud Järve külas.

Hiiemets Kalina külas.

Iis, Iijeorg, Iiekalmu, Hiiesoo, Aava iis Kohtla külas.

Iis, Iijekivi, Iije talu Konju külas.

Iijetukk Künnapõhja külas.

Martsakalda hiis Martsa külas.

Hiiemets, Hiie tõinu (mägi) Oru kandis.

Hiiemägi ja Hiie talu Peeril.

Iie talu Puru külas.

Hiiekivi Ratva külas.

Hiie talu Rutiku külas.

Hiis, Hiieallikas Pühajõe külas.

Hiiemets Pühajõe külas.

Hiis Tammiku ja Pauliku külas.

Hiiekivi, Hiiekaev Võide külas.

\section{Kadrina kihelkond}

Iijemägi, Ijekallas Arbavere külas.

Kõnnu hiis, Hiieniinepuu, Hiiepärn, Hiiepuu Ilumäe külas.

Iiemänd (Kallukse mänd, Kitlimänd) Vaiatu (Kolu) külas.

Lemminge hiis Joandu külas.

Iiealuse mets, Iijaluse heinamaa, Hiiealuse seljandik Korjuse külas.

Hiietamm Neeruti külas.

Ije saun Ohepalu külas.

Hiiepäälne, Hiiekivi Põima külas.

Iie koht, Ijesalu mets, Ijesalu kivikalme Saukse külas.

Hiiemännid Sirgu külas.

Hiiemägi, Hiiemets, Hiie- ehk Ukuallikas ja Hiie talu Soomukse külas. 
Ijeallikad, Hiie talu Uku külas.

Ijemägi Vandu külas.

Ije mets, Iije väli Vatku külas.

Iijemets, Iije sadam, Iije kari, Ijekari salm Vihasoo külas.

Iije talu Vohnja külas.

\section{Lüganuse kihelkond}

Hiis Aa külas.

Iijessuo, Hiielaukad Aidu külas.

Iijekaiv (allikas), Hiiemets Kestla külas.

Iis, Iiskülä väli, Iiekalda talu, Hiie kallas Maidla külas.

Iis, Hiie talu Ojakülas.

Iisküla oja Piilse külas.

Iiemägi, Iijemä väli, Iieväli, Iijekallas, Ijekalda-alune, Ijemää pärn, Iije talu, Hiiemets Purtse külas.

Iiemägi, Iie kallas Savala külas.

Iis, Iiemägi, Iie koht, Ijealune karjamaa, Iiemäealune, Iielinn, Iielinna ase, Iiemäe küla, Hiiemägi Soonurme külas.

Iiepõld Varja külas.

Hiiemägi Virunurme külas.

\section{Mahu (Viru-Nigula) kihelkond}

Iiemägi, Iieotsa mägi, Iiemets, Iije alligas, Iiemäe talu Iila külas.

Iie ja Hiiemagasi talud Kabala külas.

Hiieallikas Koila külas.

Iijemägi, Iiomägi Kunda külas.

Iiemets Lahe külas.

Hiiemägi, Hiiekalda kivid Malla külas.

Iijemägi, Iijemäe talu, Iijemäe saunad Miila külas.

Hiis, Hiielepik, Hiielepiku ja Hiiemäe talu Männiku külas.

Iie mägi, Iied, Iie tammik, Koumardi iis, Pärnamäe iis Pärna külas.

Tammealuse hiis Samma külas.

Iis, Iije talu Satsu külas.

Iijemägi, Iijeküla Simunamäe külas.

Iijemäe põld Siberi külas.

Hiis Varudi külas.

Iijekivi Varudi-Altkülas.

Suur iis ja Väike iis Varudi-Altkülas. 
Hiiekoht Pühajärve lepik Varudi-Vanakülas.

Iie, Iie heinamaa, Hiis Vasta külas.

Hiis Viru-Nigulas Sõja-Maarja kabeli ümbruses.

Hiis Salumägi Võrkla külas.

\section{Rakvere kihelkond}

Hiiemägi Aluvere külas.

Iijenokkade mägi, Iialuse, Iiekivi, Iie Heinamaa, Hiiekoplid Aresi külas.

Iijeleppik Kohala külas.

Iieallikas (Kulliallikas) Nurme külas.

Iijemägi, Iidumägi, Iijemäe org, Iiemäe talu Tõrma külas.

\section{Simuna kihelkond}

Hiiemäe talu Avanduse külas.

Hiiekoht Emumäe külas.

Hiiekivi Koila külas.

Hiiepuud Pruut ja Peigmees (kuusk ja mänd) Laekvere külas.

Iije talu Määri külas.

Iijemetsa talu Orguse külas.

Hiiemägi Rakke külas.

Hiis Salla külas.

Iijeküngas Sootaguse külas.

Iietammik, Iiekivi, Iije talu Tammiku külas.

Iije talu Venevere külas.

Iijemägi Väike-Tammiku külas.

\section{Vaivara kihelkond}

Iis, Iijemägi, Iijemets, Iijekivi (Kanepkaula kivi) Hiiemetsa külas.

Iis Hundinurga külas.

Iijemäe talu Jaama külas.

Iijeleppik Kannuka külas.

Iiemägi, Iiumägi, Iiuoja, Iije oja, Iiukaldad Perjatsi külas.

Iijekivi Pimestiku külas.

Iije oja, Hiieoja talu Türsamäel.

Iije koht, Iije joki, Iije talu, Iie heinamaa Udria külas. 


\section{Viru-Jaagupi kihelkond}

Tammaru Hiiemägi Mõdriku külas.

Hiiemägi, Iijeallikkad, Hiiealune, Hiieheinamaa, Hiievärav, Hiierehi, Hiieküün, Iije talu Mõdriku külas.

Iijemäe, Hiiemäe talu Pajusti külas.

Iijemägi, Hiiemäe talu Põlula külas.

Hiis Raudlepa külas.

Iijemägi, Iijemäe talu Raudvere külas.

Iis, Iielepik, Hiiekoppel, Hiiekopli tiik, Iijenukka talu, Hiiesalu talu Tudus.

Iijemägi, Hiiemäe talu Vaekülas.

Iijemägi, Iijemäe talu Vanakubja külas.

Iiemägi Voore külas.

\section{Väike-Maarja kihelkond}

Iijemägi, Iijeleppik, Iiemäe talu Aburis.

Hiiemets Ebavere mäel.

Iideaugud, Hiis Jäola külas.

Iijemää talu Kaarma külas.

Iije talu Koonu külas.

Iije talu, Hiietedre talu Kännukülas.

Taaraiije talu ja hiis Kärsa külas.

Iijemägi Risu külas.

Hiiesalu Ugurimäel Äntu külas.

\section{Kirjandus}

Altnurme, Lea 2011. Eestlased usulises pöördes. Postimees, AK nr 173, 19. märts (http:// arvamus.postimees.ee/405074/lea-altnurme-eestlased-usulises-poordes/ - 21. veebruar 2017).

Hiite Maja, Faktum Ariko 2014. Elanike hoiakud seoses hiite jt looduslike pühapaikadega. Uuringu esitlus 2014 (http://www.flaj.ut.ee/sites/default/files/www_ut/aruanne2014 faktumariko.pdf - 3. aprill 2017).

Henrik 1993 = Henriku Liivimaa kroonika 1993. Tallinn: Olion.

IUCN 2011 = Looduslikud pühapaigad. Juhend kaitsealade valitsejatele. Kaitsealade hea tava suunised nr 16. IUCN, Maavalla koda. Ecoprint (https://www.maavald.ee/ failid/IUCN_SNS_Estonia.pdf - 21. veebruar 2017).

Kaasik, Ahto 2001. Tammealuse hiis. Maavalla Koda. Koduleht (http://www.maavald. ee/maausk.html?rubriik=40\&id=28\&op=lugu -21 . veebruar 2017). 
Kaasik, Ahto 2007. Ajaloolised looduslikud pühapaigad - väärtused looduse ja kultuuri piirimail. Kaasik, Ahto \& Valk, Heiki (koost). Looduslikud pühapaigad, väärtused ja kaitse. Õpetatud Eesti Seltsi Toimetised 36. Tartu: Õpetatud Eesti Selts, lk 23-74 (https://www.flaj.ut.ee/sites/default/files/fl/hiiekogumik.pdf - 21. veebruar 2017).

Kaasik, Ahto 2011. Eesti looduslikud pühapaigad. IUCN, XII-XXI.

Kaasik, Ahto 2016. Põlised pühapaigad. Oleme hiierahvas. Tallinn: Pegasus.

Koski, Mauno 1967, 1970. Itämerensuomalaisten kielten hiisi-sanue. Semanttinen tutkimus. I: 1967; II: 1970. Turun Yliopiston Julkaisuja. Turku: Turun yliopisto.

Kütt, Auli 2007. Maarahva pühade puude ja puistutega seotud käitumisnormid. Kaasik, Ahto \& Valk, Heiki (koost). Looduslikud pühapaigad, väärtused ja kaitse. Õpetatud Eesti Seltsi Toimetised 36. Tartu: Õpetatud Eesti Selts, lk 185-212 (https://www.flaj. ut.ee/sites/default/files/fl/hiiekogumik.pdf - 21. veebruar 2017).

Mazur, Tanel 2005. Kunda Hiiemägi peitis endas üht Eesti vanemat metalleset. Eesti Päevaleht $\mathrm{nr}$ 195, 25. august (http://www.epl.ee/news/eesti/kunda-hiiemagi-peitis-endasuht-eesti-vanemat-metalleset.d?id=51017745 -21 . veebruar 2017).

Moor, Argo 1998. Hingepuu. Vanade mü̈̈tide jälgedes. Tartu: Elmatar.

Remmel, Mari-Ann 1998. Hiie ase. Hiis eesti rahvapärimuses. Tartu: Eesti Kirjandusmuuseum.

Vaher, Berk 2003. Hiis - eestlase endaksjäämise kaitseala. Postimees nr 119, 17. juuni (http://arvamus.postimees.ee/2028845/hiis-eestlase-endaksjaeaemise-kaitseala-21. veebruar 2017).

Valk, Heiki 2009. Sacred Natural Places of Estonia: Regional Aspects. Folklore: Electronic Journal of Folklore 42, lk 45-66 (http://www.folklore.ee/folklore/vol42/valk.pdf 21. veebruar 2017, doi: 10.7592/FEJF2009.42.valk).

\section{Film}

Maran, Rein 2015. Suvisted Tammealusel. Gaviafilm, dokumentaalfilm, 30 min.

Ahto Kaasik - tegutseb Tartu Ülikooli looduslike pühapaikade keskuses pühapaikade uurija ja lektorina ning on Muinsuskaitseameti looduslike pühapaikade eksperdinõukogu liige.

ahto.kaasik@ut.ee 


\section{Summary}

\section{Hiis sites in Virumaa}

Ahto Kaasik

Keywords: hiis, natural holy place, Virumaa

Hiis is Estonians' natural holy place, where, with the help of rituals and sacrifices, people tried to curry favour with their gods. Similar holy places can be found at Estonians' nearer and more distant kindred peoples. Hiis sites form a separate group among historic natural holy places. As a rule, hiis is a historic holy place of a village or a bigger community. According to folklore materials, each Estonian village used to have its own hiis site. Some of them, however, were used by the whole parish. Historical records testify to the existence of approximately 600 hiis sites in Estonia, and about a fifth of them were in Virumaa.

The territory of the hiis site can be from less than a hectare up to a hundred hectares, and different spiritual centres can be encountered on this territory: individual holy boulders, trees, springs, barrows, dancing grounds, etc.

A well-kept hiis is a primeval forest, enriching the landscape and providing shelter to many species of the living nature. Hiis sites are ancient nature reserves of our nation, which should be used only to keep historical traditions alive. Unfortunately, these kinds of hiis sites have become rare. In the past decades and centuries, most of the hiis sites were damaged or even destroyed. Even today, economic activity exerts a harmful impact on the majority of hiis sites.

The article presents a list of Virumaa hiis sites, with only historical names included, and sites resembling hiis but never called such have been excluded.

Ahto Kaasik is lecturer and researcher of sacred places at the Centre of Sacred Natural Sites at the University of Tartu, and member of the expert committee of sacred natural sites at the National Heritage Board.

ahto.kaasik@ut.ee 